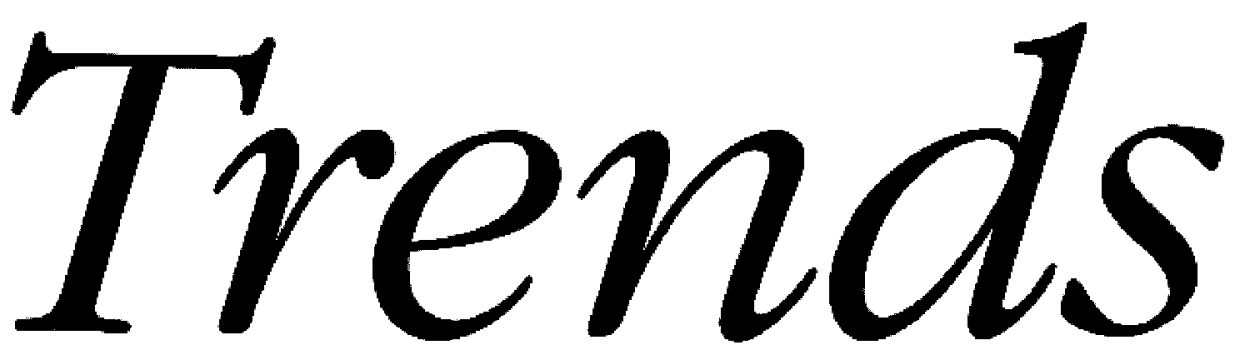

IN LAW LIBRARY MANAGEMENT AND TECHNOLOGY

Edited by Philip C. Berwick • For academic, firm, corporate, and government law librarians

\title{
Making the Leap to Management: Tips for the Aspiring and New Manager
}

By FEMI CADMus, Associate Law Librarian for Administration, Lillian Goldman Law Library, Yale Law School

1 s the result of innate ability, a fortunate few are able to effortlessly us need to plot the path to management astutely and with deliberation. Library professionals might also become "accidental" managers, finding themselves thrust into an unplanned and perhaps unwanted managerial position for which they were not prepared. This is particularly true in the current climate of constrained budgets characterized by restructurings, job freezes, and layoffs.

Most entry-level library positions do not call for managerial or supervisory skills. The question then is, how can you position yourself to enter successfully into a leadership, managerial and/or supervisory role? How can you avoid the unnecessary pitfalls of the unseasoned and untried manager and develop effective leadership and managerial skills? A threshold question is whether you have the 


\section{Trends}

ability and desire to be a manager. While being a successful manager does not solely rest on your people skills, coaching and advising employees and providing leadership for your unit are huge components of the job. If this is not your forte, you might want to consider doing something else. For those who become managers, the following tips will make the transition easier than would otherwise be the case.

\section{Develop a leadership/managerial mindset now}

Don't wait to leave your non-managerial position to discover that you have not developed the skills set to lead. Start thinking like a manger now, developing the vital leadership skills you will need in the future. This might be difficult in libraries with flat organizational structures where professional staff report to the director of the library and have limited or no supervisory responsibility. While hierarchical structures present opportunities to ascend up the management ladder, the absence of hierarchy should not be a deterrent. Geoffrey Bellman, an organizational consultant who has consulted to numerous Fortune 500 companies, contends that "some of us get trapped "on hold" waiting for the authority, waiting for others to tell us what to do. That does not work." It is definitely possible to develop influence without authority by becoming the "go to" person and the knowledge expert in your specialty area in the library. Know how to strike the balance between raising your visibility and profile without being perceived as obnoxious and pushy. Other opportunities to test the leadership waters include volunteering. Volunteering to serve on in-house and/or national library committees and even community organizations is a great way to develop team building and leadership skills.

\section{Project the right image and brand yourself}

How do your peers and colleagues perceive you? What do people think when your name is mentioned in professional circles, and what type of reputation have you cultivated for yourself? Some people underestimate the power of appearance and proper grooming. Librarians tend to be an easygoing group of career professionals who shun formal attire (more especially so in academic environments). While you 
are not dressing up for Wall Street, a crisp professional appearance is a must, if you are to be taken seriously in the workplace.

\section{Seek opportunities to practice being a manager}

My first full-time professional position was as a circulation-reference librarian. I was fortunate to work for a director who gave me the latitude to develop and carry out plans for my unit. Supervising two support staff and numerous student assistants was a great way to cut my teeth on managing people, time, and resources. If you are not in a supervisory position, do not be shy about offering to be a backup for someone who manages. This will give you much-needed exposure and practical experience.

Actively seek and pursue opportunities to lead no matter how small the project is. This requires moving out of the confines of your job description and focusing on contributing to the general mission and goals of the library. This might call for stretching yourself beyond your regular job duties and signing up for special projects.

Collaborate with other departments-this particularly rings true in an era of diminishing budgets and reduced personnel. Don't wait to be called upon to assist in other departments, identify and pursue opportunities to cross train. Remember that once you become a manager you might be managing a department in which you do not necessarily have a lot of experience. If this is the case, your prior exposure to work in other departments will prove invaluable.

This is also a great time to seek out training to correct any deficiencies. For example, budgeting is a key requirement for aspiring managers, and the ability to utilize spreadsheets and understand various systems for generating reports is essential. Now might be the time to take a course on accounting or a quick course on using Excel spreadsheets.

\section{Forge relationships}

An aspiring or new manager needs to forge relationships and build a team. Do not wait until you need a favor before networking and establishing good relationships. 


\section{Trends}

This is also the time to move away from a solo orientation to a team building mindset, working towards shared and common goals. Sometimes it seems easier and quicker to get things done when you do it yourself, especially in situations where you might have to coach and train an employee. However, in the long run, this is counterproductive. You definitely want to foster a teambuilding and a teamwork orientation, working collaboratively whenever possible. Simply put, it is essential to build a vision for your library without being bogged down with minute details by allowing others to be creative and take the initiative. In short, avoid being the dreaded micro-manager. Instead, think like a coach by inspiring, developing shared responsibility, and delegating projects.

\section{Demonstrate integrity and establish credibility}

Identify the core values of your organization and emulate them consistently. In his book Walk the Walk, Mr. Deutschman, a consultant on personal and organizational change, has this to say about leadership: "Ultimately, it doesn't depend on who you are or even what you say or how you say it, but only on what you do."2 If your library places strong emphasis on customer service, identify opportunities to consistently serve your patrons better. Credibility is lost, for example, if someone overhears you making disparaging statements about demanding patrons. Consistency is the key, and contradictory behavior needs to be avoided as the successful manager always leads by example. Recently the National Transportation Safety Board (NTSB) became the first federal agency to ban the use of wireless devices behind the wheel by its employees while on duty. The NTSB Chairwoman reportedly remarked: "Using a telephone or other electronic device while driving, even with a hands free kit, significantly increases the risk of an accident... We must lead by example."3

Strive to create a fair and equitable work environment by not creating different sets of rules and standards for employees. If you require that employees report to work at an agreed set time, it would foster a lot of resentment if you chose to turn a blind eye towards the errant employee who consistently straggles in late. Granted, there might be occasions when certain employees might be granted concessions due to special circumstances and needs. For example, a 
nursing mother might have to take breaks outside of the established break periods. Strive to communicate to other employees that the basis of such concessions fall within the framework of your library's established labor practices and that the whole unit stands to benefit from this temporary concession.

\section{Develop excellent communication and interpersonal skills}

The ability to listen and effectively convey information cannot be overstated. This establishes the difference between a great, mediocre, or even subpar manager. Be accessible and provide a forum for the exchange of ideas without fear of retribution. Accessibility is the key to fostering communication between co-workers. A successful communicator does not stay holed up in a closed office. Entertain the exchange of ideas and you'll be surprised by how much you are able to pick up about the state of affairs in the library. Suggestions are always welcome, but recognize also that your ultimate goal is to pursue the common good of the library and that you cannot always please everyone. While you do not want to marginalize the ideas or needs of any one person or group, your goal should always be the overall best interest of the library. Learn the best means of communicating and disseminating information within your library. Effective means of communicating might be through regularly scheduled meetings, email blasts, blogs, and of course one-on-one conversations. It all depends on the culture of your organization. If you are going to be a successful manager, you cannot leave your employees guessing about job duties or their unit's short- and long-term goals. Of course not all information can be shared, and some types of information are highly sensitive. Learn to recognize when and how best to share information. If you do not share information appropriately and in a timely manner, the notoriously unreliable grapevine will take over and you will find yourself spending more and more of your work day dispelling rumors.

\section{Seek out a mentor and network effectively}

It is important to establish a professional relationship with a manager whom you respect and admire. This is someone you can be open with and who can provide 


\section{Trends}

a candid assessment of your strengths and weaknesses as well as provide the career and professional guidance you need. Networking with other managers is also vital. While the value of social networking in the online world can be effective, do not neglect to maintain real-life contacts with people who can contribute to your professional aspirations.

The leap to management in reality is mostly not a leap, but an early recognition of a desire to serve in the capacity of a coach, a manager, and a leader. Recognizing this goal early in one's career is a necessary step towards identifying opportunities and plotting the path successfully.

\section{Notes}

I. Geoffrey M. Bellman, Getting Things Done When You Are Not in Charge (San Francisco, CA: Berrett-Koehler Publishers Inc, 200I), p. I.

2. Alan Deutschman, Walk the Walk: The \#I Rule for Real Leaders (New York, NY: Penguin, 2009), p. 157.

3. NTSB Workers to Hang Up Cells, USA Today, Wed., Sept. 9, 2009, at 3A.

Femi Cadmus, Associate Director for Administration \& Lecturer in Legal Research, the Lillian Goldman Law Library, Yale Law School, New Haven, Connecticut.Email.<femi.cadmus@yale.edu>

Trends is published by

William S. Hein \& Co., Inc.

I285 Main St. / Buffalo, NY I4209

Phone: (800) 828-757I; (716) 882-2600

Fax: (716) 883-8100

Email: mail@wshein.com

ISSN 0893-6773

The complete collection of articles published

in Trends is available in HeinOnline

(http://heinonline.org)
Editor: Philip C. Berwick, Associate Dean

for Information Resources

Washington University School of Law

Law Library

Campus Box II7I

St. Louis, MO 63130

Phone: (3I4) 935-4042; Fax: (3I4) 935-7I25

Email:<BERWICK@WULAW.WUSTL.EDU>

(C) 2009 by William S. Hein \& Co., Inc. 